\title{
Biparental inheritance of plastidial and mitochondrial DNA and hybrid variegation in Pelargonium
}

\author{
Andreas Weihe $\cdot$ Janina Apitz $\cdot$ Frank Pohlheim • \\ Annabel Salinas-Hartwig · Thomas Börner
}

Received: 31 July 2009/Accepted: 14 September 2009/Published online: 29 September 2009

(C) The Author(s) 2009. This article is published with open access at Springerlink.com

\begin{abstract}
Plastidial (pt) and mitochondrial (mt) genes usually show maternal inheritance. Non-Mendelian, biparental inheritance of plastids was first described by Baur (Z Indukt Abstamm Vererbungslehre 1:330-351, 1909) for crosses between Pelargonium cultivars. We have analyzed the inheritance of $\mathrm{pt}$ and mtDNA by examining the progeny from reciprocal crosses of Pelargonium zonale and $P$. inquinans using nucleotide sequence polymorphisms of selected pt and mt genes. Sequence analysis of the progeny revealed biparental inheritance of both pt and mtDNA. Hybrid plants exhibited variegation: our data demonstrate that the inquinans chloroplasts, but not the zonale chloroplasts bleach out, presumably due to incompatibility of the former with the hybrid nuclear genome. Different distribution of maternal and paternal sequences could be observed in different sectors of the same leaf, in different leaves of the same plant, and in different plants indicating random segregation and sorting-out of maternal and paternal plastids and mitochondria in the hybrids. The substantial transmission of both maternal and paternal mitochondria to the progeny turns Pelargonium into a particular interesting subject for studies on the inheritance, segregation and recombination of $\mathrm{mt}$ genes.
\end{abstract}

Keywords Mitochondria - Chloroplasts . Biparental inheritance $\cdot$ Heteroplasmy $\cdot$ Pelargonium

Communicated by R. Hagemann.

\footnotetext{
A. Weihe · J. Apitz · A. Salinas-Hartwig · T. Börner $(\bowtie)$ Institut für Biologie, Humboldt-Universität zu Berlin, Chausseestr. 117, 10115 Berlin, Germany

e-mail: thomas.boerner@rz.hu-berlin.de

F. Pohlheim

Brodberg 38, 14532 Kleinmachnow, Germany
}

\section{Introduction}

One hundred years ago, Baur (1909) described in the first volume of this journal the non-Mendelian inheritance of green versus chlorophyll-deficient leaf phenotypes in crosses between different Pelargonium cultivars. Baur developed a theory about the origin of periclinal chimeras by segregation and sorting-out of different types of chloroplasts/plastids and explained the non-Mendelian pattern of inheritance by biparental transmission of chloroplasts to the progeny. This publication marks the starting point of organellar genetics. In the same volume, Correns (1909) described the maternal inheritance of pigment-deficiencies in crosses between Mirabilis jalapa plants. These data were only later correctly interpreted as evidence for maternal inheritance of chloroplasts/chloroplast genes (see Hagemann 2002). The uniparental maternal inheritance is the most common mode of inheritance of chloroplast/ plastidial (pt) genes in angiosperms (Corriveau and Coleman 1988; Zhang et al. 2003), although a rare contribution of paternal chloroplasts to the progeny may be detected even in species that are regarded as strictly maternal in their chloroplast inheritance (Azhagiri and Maliga 2007 and references therein). Uniparental paternal inheritance of pt genes occurs in the angiosperm genus Actinidia (Cipriani et al. 1995; Chat et al. 1999) and in many species of gymnosperms (Hagemann 2004 and references therein). Biparental inheritance of plastids can lead to hybrid variegation if one of the two parental types of plastids/chloroplasts bleaches out leading to chlorophyll-deficient leaf sectors, while the other chloroplast type remains normally green. Hybrid variegation indicates that one of the two parental plastid types has failed to develop and/or green normally in the hybrid cell (Metzlaff et al. 1982; Stubbe 1989). 
Almost all eukaryotes have mitochondria; the mitochondria are inherited exclusively from the maternal parent more commonly than is the case for plastids (e.g. Wallace 2007). Mitochondrial (mt) genes are maternally inherited in the great majority of plant species (reviewed in Mogensen 1996; Birky 2001; Hagemann 2004; Barr et al. 2005). Occasional transmission of paternal mtDNA has been reported for a variety of fungal, plant and animal species including human that usually show maternal inheritance of mitochondria. Biparental transmission has been discussed as precondition for putative recombinant $\mathrm{mt}$ genomes (e.g. Awadalla et al. 1999; see Jaramillo-Correa and Bousquet 2005; Dowton et al. 2003; Barr et al. 2005; Ujvari et al. 2007 for further references). It should be emphasized that thorough investigations into the mode of inheritance of $\mathrm{mt}$ genes are rare and some published data certainly need further confirmation.

Pelargonium species are among those plants which show a nearly equal transmission of maternal and paternal plastids to the progeny (Hagemann 2004) and might therefore be particularly interesting subjects for studying the inheritance of $\mathrm{mt}$ genes. We have studied the transmission of ptDNA and mtDNA in crosses between Pelargonium zonale and $P$. inquinans. Biparental inheritance of plastids in these crosses is suggested by the phenotype of the hybrid plants, since they have variegated leaves. By assessing sequence polymorphisms, this report demonstrates biparental inheritance of both ptDNA and mtDNA.

\section{Materials and methods}

Plant material

We studied leaves of $P$. zonale (L.) l'Herit, ex Ait., $P$. inquinans (L.) l'Herit, ex Ait., and of the reciprocal crosses $P$. zonale $\times P$. inquinans, and $P$. inquinans $\times P$. zonale. The original crosses were made with one plant of each species in 1984. The cross $P$. zonale $\times P$. inquinans resulted in 5 bleached, 2 variegated and 23 green seedlings, the cross $P$. inquinans $\times P$. zonale in 3 bleached, 8 variegated and 2 green seedlings (Pohlheim 1986). The two parental and four variegated hybrid plants have been maintained in a greenhouse. Cuttings were made from branches of the parental plants and four variegated hybrid plants (two $P$. inquinans $\times P$. zonale $-i \times z I$ and $I I$, and two $P$. zonale $\times P$. inquinans $-z \times i I I I$ and $I V)$ in 2007 . Plants (cuttings) belonging to the same clone (i.e. originating from the same plant) were given identical clone numbers (I-IV) and a plant-specific number. During the current study, the plants were kept under long day (12 h light/8 h darkness) conditions.

DNA isolation

For amplification of organelle gene fragments, total DNA was isolated from single leaf discs of $4 \mathrm{~mm}$ diameter which were crushed with a pipette tip in $400 \mu \mathrm{l}$ of $200 \mathrm{mM}$ Tris$\mathrm{HCl}, \mathrm{pH}$ 8.0, $250 \mathrm{mM} \mathrm{NaCl}, 25 \mathrm{mM}$ EDTA, 0.5\% SDS, incubated for $15 \mathrm{~min}$ at $50^{\circ} \mathrm{C}$, and centrifuged for $15 \mathrm{~min}$ at $14,000 \mathrm{rpm}$. The supernatant was precipitated with $400 \mu \mathrm{l}$ isopropanol, centrifuged, and the pellet washed with $70 \%$ ethanol. The final pellet was dissolved in $250 \mu \mathrm{l}$ $2.5 \mathrm{M}$ ammonium acetate, incubated for $5 \mathrm{~min}$ on ice and centrifuged for $10 \mathrm{~min}$ at $14,000 \mathrm{rpm}, 4^{\circ} \mathrm{C}$, to remove RNA and debris. DNA was precipitated from the supernatant with ethanol and dissolved in $50 \mu \mathrm{l}$ double-distilled water.

Amplification of chloroplast and mitochondrial gene fragments

Mitochondrial gene fragments of atpl, cox2, cox3, and $c o b$, and of the chloroplast intergenic region between $r p o B$ and $\operatorname{trn} C^{G C A}$ (see Table 1 for lengths and sequence polymorphisms) were amplified by polymerase chain reaction (PCR). Primer sequences were designed from GenBank entries of the mt gene fragments [accession numbers DQ317063 (atp1), DQ317069 (cox2), DQ317067 (cox3), DQ317065 (cob)] and the total pt DNA sequence (accession number DQ897681) of Pelargonium $\times$ hortorum. $50 \mu 1$ reactions contained $5 \mu \mathrm{l} 10 \times$ reaction buffer, $1 \mu \mathrm{l} 10 \mathrm{mM}$ dNTP, 10 pmol each of primers AAGGTGATCTTGTGAAGCG AACTG and GTCTGACCCAAATTGAGCAAAGG-3 (atpl), CCGTGGCAAGTGGGATTTC and GTACTGC ATCGCACTTCACACC ( $\operatorname{cox} 2)$, CTATGGGGATTTGGT TCCTTAG and AGAAACAATCAGCCAATAACAAGA $(c o b)$, GTTTGGTGGCGTGATGTTACAC and CCAC AAAGTGCCAATACCAGG (cox3), or CATTATTGGCT CATTCTTCATC and TTCCCTAAAGGACACGAAAC $\left(\right.$ rpoB-trn $\left.C^{G C A}\right)$, respectively, $1 \mu \mathrm{l}$ of template DNA, and 2.5 units Taq polymerase. Reactions were incubated for $1 \mathrm{~min}$ at $95^{\circ} \mathrm{C}$, and then run for 40 cycles at $94^{\circ} \mathrm{C}$ for $30 \mathrm{~s}$, $63^{\circ} \mathrm{C}(a t p 1, \operatorname{cox} 2, \operatorname{cox} 3, c o b)$ or $56^{\circ} \mathrm{C}\left(r p o B-t r n C^{G C A}\right)$ for $30 \mathrm{~s}$, and $72^{\circ} \mathrm{C}$ for $60 \mathrm{~s}$. The amplicons were separated electrophoretically on $1 \%$ agarose gels, cut out from the gel under UV light, and the DNA was purified using Qiagen spin columns according to the instructions of the manufacturer. The fragments were sequenced directly using amplification primers and BigDye terminator chemistry (Applied Biosystems). 
Table 1 Nucleotide polymorphism in organelle sequences of $P$. zonale and $P$. inquinans

\begin{tabular}{|c|c|c|c|}
\hline & Plastidial & Mitochondrial & Mitochondrial \\
\hline & $r p o B-\operatorname{trn} C^{G C A}$ & atpl & $\cos 3$ \\
\hline P. zonale & AA $\cdots$ GC & TCTGAAT & CTGATT \\
\hline P. inquinans & AATAAAAGC & TCAACAT & СТTCTT \\
\hline $\begin{array}{l}\text { Amplicon length } \\
\text { (bp) }\end{array}$ & $840 / 845$ & 980 & 571 \\
\hline Position $^{\mathrm{a}}$ & $213-217$ & $316-318$ & $483-484$ \\
\hline
\end{tabular}

${ }^{a}$ From nucleotide +1 of the amplicons

\section{Results}

Characterization of molecular markers

To monitor the mode of inheritance of both plastids and mitochondria, we employed pt and $\mathrm{mt}$ gene fragments showing sequence polymorphism between the two parental species, $P$. zonale and $P$. inquinans, as molecular markers. Four mt gene fragments (atpl, cox2, cox3, cob) were amplified from $P$. zonale and $P$. inquinans using primers derived from sequence database entries (see "Material and methods"). While cox2 and cob fragments showed exactly the same sequence in both parents (data not shown), nucleotide polymorphisms were detected within the cox3 and the atpl fragments [sequences available at EMBL under accession numbers FN545845 and FN545843 (atpl), and FN545844 and FN545848 (cox3), respectively]. A region between the pt genes $r p o B$ and $\operatorname{trn} C^{G C A}$ was also found to differ between $P$. zonale and $P$. inquinans (EMBL accession numbers FN545846 and FN545847; see Table 1). These sequences, exhibiting nucleotide substitutions in the mt fragments and an indel in the pt fragment, respectively, were subsequently used as molecular markers for the $\mathrm{mt}$ and $\mathrm{pt}$ genomes.

Inheritance of organellar genes

Hybrid plants could easily be identified by the color of their flowers (pink) as opposed to white/slightly pink in case of the $P$. zonale clone used in our study, and red in case of $P$. inquinans. Moreover, many hybrid leaves, but never leaves of the parental plants, showed a variegated pattern of pale green/yellowish/whitish and green sectors (Fig. 1; Pohlheim 1986). The degree of bleaching varied between the plants and leaves as described previously (Pohlheim 1986). Sequence analysis of the molecular markers, the pt intergenic region rpoB-trn $C^{G C A}$ and the mt genes atpl and cox3 (Table 1), was performed on two samples taken from one leaf each of three plants per hybrid clone and from several plants of the parental species, $P$. zonale and $P$. inquinans. As hybrids, plants resulting from the reciprocal crosses $P$. inquinans $\times P$. zonale $(i \times z$, clones $I$ and $I I)$ and $P$. zonale $\times P$. inquinans $(z \times i$, clones $I I I$ and $I V)$ were selected for the analyses. We isolated total DNA
Fig. 1 a-c Flowers of Pelargonium zonale,

$P$. inquinans $\times P$. zonale and $P$. inquinans. d, e Whole plant and leaf of $P$. inquinans $\times$ $P$. zonale hybrid. Note the variegation due to sorting-out of maternal and paternal plastids in the hybrid leaves of one shoot. $m$ sector with maternal chloroplast rpoB-trnC $C^{G C A}$ sequence, $b p$ sector with maternal and paternal (biparental) rpoB-trn $C^{G C A}$ sequences

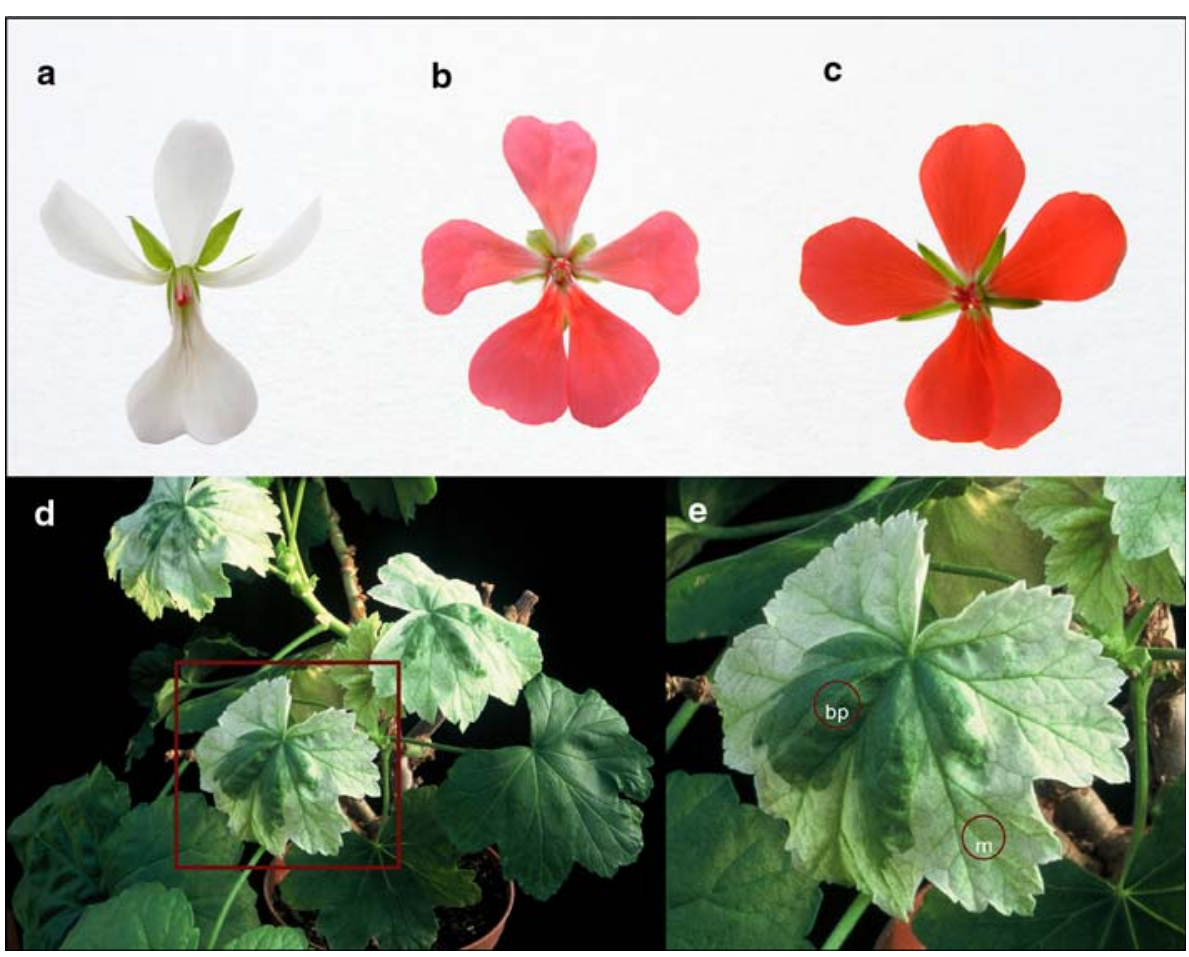


from the leaf material allowing for analysis of $\mathrm{mt}$ and $\mathrm{pt}$ sequences in the same samples. To account for the expected segregation of the parental organelles, samples were taken from different parts of the leaves (center and edges). Results of the analyses are shown in Table 2.

The DNA samples were screened for the presence of the maternal and/or paternal mtDNA polymorphisms, using as molecular markers the parent-specific sequences of atpl and cox3. In only one of the hybrids $(z \times i$ III), we observed the maternal $\mathrm{mt}$ sequences were predominant, with one sample having both maternal and paternal polymorphisms, indicating that the tissue had inherited the mitochondria biparentally. Two of the hybrids $(z \times i \mathrm{IV}$ and $i \times z \quad I I)$ showed the opposite pattern: paternal sequences were most abundant, with a few samples having both parental mtDNAs. The fourth hybrid $(i \times z I)$ contained only paternal $\mathrm{mt}$ sequences observed in the six samples from the leaves of three plants (Table 2). The presence of both maternal and paternal mt sequences in the same sample was more often observed in the center of the leaves than at the edges. The detection of both paternal and maternal $\mathrm{mt}$ polymorphisms in the hybrid plants demonstrates biparental inheritance of mtDNA in Pelargonium.

The same samples were studied for ptDNA polymorphisms. Maternal sequences prevailed in $i \times z I, i \times z I I$ and $z \times i I I I$, whereas we found mostly the paternal $\mathrm{pt}$ polymorphism in $z \times i I V$ (Table 2 ). The results clearly demonstrate biparental inheritance of chloroplast DNA in the studied crosses. Toward the center of the leaf, the sectors were green and 7 out of 12 were characterized as containing both parental ptDNAs, whereas the edges had predominantly either one or the other plastid type (see Table 2). A similar observation was made for mtDNA (see above). The reason for this observation could be that the central regions of the leaves are formed from three layers of the meristem (LI, II, III), whereas the edges are build up only from two layers (LI, LII). Different layers of the meristems may contain genetically different chloroplasts

Table 2 Analysis of inheritance of plastidial and mitochondrial sequence polymorphism in reciprocal crosses of Pelargonium

\begin{tabular}{|c|c|c|c|c|c|c|c|c|c|}
\hline \multirow{2}{*}{$\begin{array}{l}\text { Species, } \\
\text { hybrid }\end{array}$} & \multirow{2}{*}{$\begin{array}{l}\text { Plant, } \\
\text { sample }\end{array}$} & \multicolumn{2}{|c|}{ Plastid rpoB-trn $C^{G C A}$} & \multirow{2}{*}{$\begin{array}{l}\text { Origin of pt } \\
\text { sequence }\end{array}$} & \multicolumn{2}{|c|}{ Mitochondrial atp1 } & \multicolumn{2}{|c|}{ Mitochondrial cox3 } & \multirow{2}{*}{$\begin{array}{l}\text { Origin of } \mathrm{mt} \\
\text { sequence }\end{array}$} \\
\hline & & $\mathrm{AA} \ldots \ldots \mathrm{GC}$ & AATAAAAGC & & ATCTGAATT & ATCAACATT & CTGATT & СТTCTT & \\
\hline P. zonale & & + & - & & + & - & + & - & \\
\hline P. inquinans & & - & + & & - & + & - & + & \\
\hline \multirow[t]{6}{*}{$i \times z I$} & $1 \mathrm{c}$ & $(+)$ & + & Biparental & + & - & + & - & Paternal \\
\hline & $1 \mathrm{e}$ & - & + & Maternal & + & - & + & - & Paternal \\
\hline & $2 \mathrm{c}$ & + & $(+)$ & Biparental & + & - & + & - & Paternal \\
\hline & $2 \mathrm{e}$ & + & $(+)$ & Biparental & + & - & + & - & Paternal \\
\hline & $3 \mathrm{c}$ & - & + & Maternal & + & - & + & - & Paternal \\
\hline & $3 \mathrm{e}$ & - & + & Maternal & + & - & + & - & Paternal \\
\hline \multirow[t]{6}{*}{$i \times z I I$} & $1 \mathrm{c}$ & + & $(+)$ & Biparental & + & - & + & - & Paternal \\
\hline & $1 \mathrm{e}$ & - & + & Maternal & + & - & + & - & Paternal \\
\hline & $2 \mathrm{c}$ & $(+)$ & + & Biparental & + & - & + & - & Paternal \\
\hline & $2 \mathrm{e}$ & - & + & Maternal & + & - & + & - & Paternal \\
\hline & $3 \mathrm{c}$ & $(+)$ & + & Biparental & + & $(+)$ & + & - & Biparental \\
\hline & $3 \mathrm{e}$ & - & + & Maternal & + & - & + & - & Paternal \\
\hline \multirow[t]{6}{*}{$z \times i I I I$} & $1 \mathrm{c}$ & + & - & Maternal & + & - & + & - & Maternal \\
\hline & $1 \mathrm{e}$ & + & - & Maternal & + & - & + & - & Maternal \\
\hline & $2 \mathrm{c}$ & + & - & Maternal & + & - & + & - & Maternal \\
\hline & $2 \mathrm{e}$ & + & - & Maternal & + & - & + & - & Maternal \\
\hline & $3 \mathrm{c}$ & + & - & Maternal & + & $(+)$ & + & - & Biparental \\
\hline & $3 \mathrm{e}$ & + & - & Maternal & + & - & + & - & Maternal \\
\hline \multirow[t]{6}{*}{$z \times i I V$} & $1 \mathrm{c}$ & + & $(+)$ & Biparental & - & + & $(+)$ & + & Biparental \\
\hline & $1 \mathrm{e}$ & - & + & Paternal & - & + & + & $(+)$ & Biparental \\
\hline & $2 \mathrm{c}$ & $(+)$ & + & Biparental & - & + & - & + & Paternal \\
\hline & $2 \mathrm{e}$ & - & + & Paternal & - & + & - & + & Paternal \\
\hline & $3 \mathrm{c}$ & - & + & Paternal & - & + & - & + & Paternal \\
\hline & $3 \mathrm{e}$ & - & + & Paternal & - & + & $(+)$ & + & Biparental \\
\hline
\end{tabular}

Samples were taken from up to three plants from the center (c) and the edges (e) of leaves (column 2$) ;+$, sequence variant detected; $(+)$, sequence variant detected with weak signal; - , sequence variant absent 
(Baur 1909; Kirk and Tilney-Bassett 1967), and the same is probably true for mitochondria. However, the number of samples analyzed is too low to deduce from these results a significant difference in the segregation of organelles between the central and outer parts of the leaves and between different layers of meristems.

\section{$P$. inquinans chloroplasts bleach out in hybrid plants}

The observed segregation of the maternal and paternal organelles in the leaves results in sorting-out of the maternal and paternal plastids which can be visually followed in the investigated material, since one type of plastids bleaches out leading to pale green (also yellowishwhitish) or variegated pale green-yellowish/dark green leaf sectors. We have analyzed green leaf segments and sectors exhibiting different grades of bleaching from hybrid plants (Fig. 1). Samples were taken from fully green, variegated and from bleached leaf sectors. In the pale green/bleached parts of the leaves, the $P$. inquinans plastid type was found, whereas in samples of variegated and green parts both types of the parental plastids could be detected. The analyzed plants originating from one of the hybrids $(P$. zonale $\times P$. inquinans clone $I I I)$ did not show hybrid variegation, but had dark green leaves like the parental plants. Here we observed a sortingout toward $P$. zonale plastids (Table 2). We observed no correlation of different leaf colors with maternal or paternal mt polymorphisms.

\section{Discussion}

Biparental inheritance of chloroplast genes in Pelargonium was demonstrated at the level of DNA by Metzlaff et al. (1981). We extended the investigation of organellar inheritance in Pelargonium by including mt markers, and we show here that mtDNA is also inherited biparentally.

Angiosperms transmitting pt genes via the pollen have been classified by Hagemann (2004) into subtype a, with a predominantly maternal transmission as found in Oenothera and Hypericum, subtype b (e.g. Pelargonium), with nearly equal contribution by the maternal and paternal parent, and the subtype c known from Medicago, with predominantly paternally transmitted plastids. Our data indicate also a substantial contribution of chloroplasts by both parents in the crosses analyzed in this study. We found in three of the investigated clones mostly or exclusively the maternal type of chloroplast, as probed with the chloroplast $r p o B$-trn $C^{G C A}$ intergenic region, but in one clone $(z \times i I V)$ mostly the paternal type. These data are in agreement with phenotypic analysis of the hybrid F1 of the original crosses between $P$. zonale and $P$. inquinans which suggested a somewhat larger transmission of maternal versus paternal chloroplasts to the progeny (Pohlheim 1986). Only the inquinans type of pt sequences was detected in pale green/ yellowish parts of hybrid leaves, while the existence of zonale plastids correlated with dark green tissue. This observation is typical for the phenomenon of hybrid variegation, previously analyzed in other Pelargonium hybrids (Metzlaff et al. 1982). Hybrid variegation is coupled to biparental inheritance of plastids and observed if the genome of one type of the parental plastids is not compatible with the nuclear genome of the hybrid, leading to impaired chloroplast development and chlorophyll deficiency. This phenomenon has been studied intensively in Oenothera (Stubbe 1989; Greiner et al. 2008). According to our data, it is the plastome of $P$. inquinans that is not fully compatible with the nuclear genome of the hybrid analyzed in the current study, while zonale chloroplasts develop normally.

Remarkably, mtDNA was transmitted from both parental plants to the hybrid progeny. The biparental inheritance of Pelargonium mitochondria was predicted because they had been detected in the sperm cells (Kuroiwa et al. 1993), zygote and the pro-embryo at the two-cell stage (Guo and $\mathrm{Hu}$ 1995) by fluorescence and electron microscopy. Yet, though paternal mitochondria may be present in sperm cells and even enter the egg cell, their exclusive maternal inheritance is not excluded since one type of mitochondria may still be specifically degraded after fertilization, as suggested by fluorescent live imaging studies in Arabidopsis (Matsushima et al. 2008) and known from detailed investigations into organellar inheritance in Chlamydomonas (Aoyama et al. 2006) and other organisms including human (Sutovsky et al. 2004). The mode of inheritance of chloroplast genes is not a reliable indicator for the manner of transmission of $\mathrm{mt}$ genes. Several cases of different parental origin of ptDNA and mtDNA in one and the same hybrid plant have been reported (Brennicke and Schwemmle 1984; Neale and Sedoroff 1991; Muschner et al. 2006).

Although the paternal type of mtDNA polymorphisms prevailed in three out of the four individual plants investigated, we would need further data from more hybrid plants/clones to conclude that more paternal than maternal mitochondria are transmitted to the progeny in crosses of $P$. zonale with $P$. inquinans. We would rather deduce from the present results that, as in the case of chloroplasts, the contribution of mitochondria by both parents is substantial. There are a few cases of mt heteroplasmy in natural and experimentally generated hybrids that are interpreted to be due to "paternal leakage", i.e. exceptional transmission of paternal mitochondria by plants that usually show a maternal inheritance of their $\mathrm{mt}$ genes (reviewed by Hagemann 2004; Barr et al. 2005). Yet, to our knowledge, a genuine biparental inheritance of mtDNA as shown here for Pelargonium has not been published yet. 
It is evident that the segregation of chloroplasts and mitochondria within the hybrid plants occurs independently from each other. In particular, the hybrid clones $i \times z I$ and $i \times z I I$ contained mostly maternal ptDNA and paternal mtDNA polymorphisms, while in $z \times i$ III the maternal, and in $z \times i I V$ the paternal sequence types of both organelles were dominating. Only in a few samples did paternal and maternal sequences of ptDNA and/or mtDNA occur together (Table 2) pointing to complete sorting-out of the maternal and paternal organelles in most parts of the leaves. This is not unexpected since the original crosses were made more than 20 years ago and sorting-out of the chloroplasts is known to occur rapidly in Pelargonium leading already at an early stage of plant development to leaf sectors or complete leaves containing only one type (maternal or paternal) of the chloroplasts (Kirk and TilneyBassett 1967). There is not much known yet about the segregation and sorting-out of maternal and paternal mitochondria during plant development (Al-Faifi et al. 2008). Biparental polymorphism of mtDNA was detected with either the atpl or the cox3 marker (Table 2), although the presence of the paternal and maternal allele of both genes should be expected. This could possibly be explained by the low abundance of one of the two gene versions [as indicated by $(+)$ in Table 2 ; from the sequence data we estimate that only about $5 \%$ to maximally $10 \%$ of the sequences were represented by the minor polymorphism] in most DNA samples where maternal and paternal sequences were detected. According to our data on the distribution of maternal and paternal atp 1 and $\operatorname{cox} 3$ sequences in the hybrid plants and in individual leaves, segregation and sorting-out of mitochondria may occur in a similar manner as is the case of chloroplasts. The lower number of 'biparental' samples containing both maternal and paternal types of $\mathrm{mt}$ sequences compared to pt sequences might indicate a higher rate of complete sorting-out in the case of mitochondria.

The interpretation of data concerning segregation of maternal and paternal types of $\mathrm{mt}$ polymorphism is complicated by the phenomenon of frequent fusion and fission of mitochondria (Logan 2006) and three specific features of plant mt genomes: (1) the $\mathrm{mt}$ genes are located on subgenomic molecules of different sizes and shapes, (2) mtDNA shows a high rate of intragenomic and potentially also intergenomic recombination (Backert et al. 1997; Fauron et al. 2005; Logan 2006; Bendich 2007), and (3) sublimons exist, composed of subgenomic molecules that occur at very low frequencies and are not detected in restriction fragment patterns of plant mtDNA (Small et al. 1989). Changes in the nuclear genome (mutations, also new combinations of alleles by sexual crossing or protoplast fusion) may lead to the amplification of sublimons to the level of normal mtDNA molecules (Arrieta-Montiel et al. 2001; Abdelnoor et al. 2003; Zaegel et al. 2006) thus leading to apparently new mt genotypes without recombination. We have carefully checked the parental species for the presence of the $\mathrm{mt}$ polymorphism of the other species, but have never detected the mt polymorphism-specific for $P$. zonale in $P$. inquinans samples and vice versa. Thus, we interpret the observation of zonale- and inquinans-specific mtDNA sequences in the hybrids as an indication of biparental inheritance and not of substoichiometric shifting. However, the observation of a zonale-specific or inquinans-specific mtDNA sequence in samples of the hybrids does not necessarily mean that the complete mt genomes of both parental species are present in these samples. Fusion of maternal and paternal mitochondria is expected to occur in the zygote or later during development of the hybrid embryo and/or plant. Therefore, recombination events may have altered the $\mathrm{mt}$ genomes. It is also not clear whether maternal and paternal subgenomic molecules may segregate independently of each other and in this way contribute to variability in the hybrid $\mathrm{mt}$ genomes. Our observations of biparental inheritance of mtDNA and substantial transmission of mitochondria from both parents to the progeny in Pelargonium open the door to further investigations into recombination and segregation of mtDNA in combination with sexual reproduction in higher plants.

Acknowledgments We thank A. Pötter for maintaining the Pelargonium plants at the greenhouse.

Open Access This article is distributed under the terms of the Creative Commons Attribution Noncommercial License which permits any noncommercial use, distribution, and reproduction in any medium, provided the original author(s) and source are credited.

\section{References}

Abdelnoor RV, Yule R, Elo A, Christensen AC, Meyer-Gauen G, Mackenzie SA (2003) Substoichiometric shifting in the plant mitochondrial genome is influenced by a gene homologous to MutS. Proc Natl Acad Sci USA 100:5968-5973

Al-Faifi S, Meyer JDF, Garcia-Mas J, Monforte AJ, Havey MJ (2008) Exploiting synteny in Cucumis for mapping of Psm: a unique locus controlling paternal mitochondrial sorting. Theor Appl Genet 117:523-529

Aoyama H, Hagiwara Y, Misumi O, Kuroiwa T, Nakamura S (2006) Complete elimination of maternal mitochondrial DNA during meiosis resulting in the paternal inheritance of the mitochondrial genome in Chlamydomonas species. Protoplasma 228:231-242

Arrieta-Montiel M, Lyznik A, Woloszynska M, Janska H, Tohme J, Mackenzie SA (2001) Tracing evolutionary and developmental implications of mitochondrial substoichiometric shifting in the common bean. Genetics 158:851-864

Awadalla P, Eyre-Walker A, Maynard-Smith J (1999) Linkage disequilibrium and recombination in hominid mitochondrial DNA. Science 286:2524-2525

Azhagiri AK, Maliga P (2007) Exceptional paternal inheritance of plastids in Arabidopsis suggests that low-frequency leakage of plastids via pollen may be universal in plants. Plant $\mathrm{J} 52$ : $817-823$ 
Backert S, Nielsen BL, Börner T (1997) The mystery of the rings: structure and replication of mitochondrial genomes from higher plants. Trends Plant Sci 2:477-484

Barr CM, Neiman M, Taylor DR (2005) Inheritance and recombination of mitochondrial genomes in plants, fungi and animals. New Phytol 168:39-50

Baur E (1909) Das Wesen und die Erblichkeitsverhältnisse der "Varietas albomarginatae hort." von Pelargonium zonale. $\mathrm{Z}$ Indukt Abstamm Vererbungslehre 1:330-351

Bendich AJ (2007) The size and form of chromosomes are constant in the nucleus, but highly variable in bacteria, mitochondria and chloroplasts. Bioessays 29:474-483

Birky CW (2001) The inheritance of mitochondrial and chloroplast genes: laws, mechanisms and evolution. Annu Rev Genet 35:125-148

Brennicke A, Schwemmle B (1984) Inheritance of mitochondrial DNA in Oenothera berteriana and Oenothera odorata hybrids. Z Naturforsch 39c:191-192

Chat J, Chalak L, Petit RJ (1999) Strict paternal inheritance of chloroplast DNA and maternal inheritance of mitochondrial DNA in intraspecific crosses of kiwifruit. Theor Appl Genet 99:314-322

Cipriani G, Testolin R, Morgante M (1995) Paternal inheritance of plastids in interspecific hybrids of the genus Actinidia revealed by PCR-amplification of chloroplast DNA fragments. Mol Gen Genet 247:693-697

Correns C (1909) Vererbungsversuche mit blass(gelb)grünen und buntblättrigen Sippen bei Mirabilis jalapa, Urtica pilulifera und Lunarium аппиа. Z Indukt Abstamm Vererbungslehre 1:291-329

Corriveau JS, Coleman AW (1988) Rapid screening method for detection of potential biparental inheritance of plastid DNA and results of over 200 angiosperm species. Am J Bot 75:1443-1458

Dowton M, Castro LR, Campbel SL, Bargon SD, Austin AD (2003) Frequent mitochondrial gene rearrangements at the hymenopteran nad3-nad5 junction. J Mol Evol 56:517-526

Fauron C, Allen J, Clifton S, Newton K (2005) Plant mitochondrial genomes. In: Daniel $\mathrm{H}$, Chase $\mathrm{C}$ (eds) Molecular biology and biotechnology of plant organelles. Springer, Dordrecht, pp 151-177

Greiner S, Wang X, Herrmann RG, Rauwolf U, Mayer K, Haberer G, Meurer J (2008) The complete nucleotide sequences of the 5 genetically distinct plastid genomes of Oenothera, subsection Oenothera: II. A microevolutionary view using bioinformatics and formal genetic data. Mol Biol Evol 25:2019-2030

Guo FL, Hu SY (1995) Cytological evidence of biparental inheritance of plastids and mitochondria in Pelargonium. Protoplasma 186:201-207

Hagemann R (2002) Milestones in plastid genetics of higher plants. Prog Bot 63:5-51

Hagemann R (2004) The sexual inheritance of plant organelles. In: Daniel H, Chase C (eds) Molecular biology and biotechnology of plant organelles. Springer, Dordrecht, pp 93-113

Jaramillo-Correa JP, Bousquet J (2005) Mitochondrial genome recombination in the zone of contact between two hybridizing conifers. Genetics 171:1951-1962
Kirk JTO, Tilney-Bassett RAE (1967) The plastids. Freeman and Co., London

Kuroiwa T, Kawazu T, Ushida H, Ohta T, Kuroiwa H (1993) Direct evidence of plastid DNA and mitochondrial DNA in sperm cells in relation to biparental inheritance of organelle DNA in Pelargonium zonale by fluorescence/electron microscopy. Eur J Cell Biol 62:307-313

Logan DC (2006) Plant mitochondrial dynamics. Biochim Biophys Acta 1763:430-441

Matsushima R, Hamamura Y, Higashiyama T, Arimura S, Sodmergen, Tsusumi N, Sakamoto W (2008) Mitochondrial dynamics in plant male gametophyte visualized by fluorescent live imaging. Plant Cell Physiol 49:1074-1083

Metzlaff M, Börner T, Hagemann R (1981) Variations of chloroplast DNAs in the genus Pelargonium and their biparental inheritance. Theor Appl Genet 59:37-41

Metzlaff M, Pohlheim F, Börner T, Hagemann R (1982) Hybrid variegation in the genus Pelargonium. Curr Genet 5:245-249

Mogensen HL (1996) The hows and whys of cytoplasmic inheritance in seed plants. Am J Bot 83:383-404

Muschner VC, Lorenz-Lemke AP, Vecchia M, Bonatto SL, Salzano FM, Freitas LB (2006) Differential organellar inheritance in Passiflora's (Passifloraceae) subgenera. Genetica 128:449-453

Neale DB, Sedoroff RR (1991) Paternal inheritance of chloroplast DNA and maternal inheritance of mitochondrial DNA in loblolly-pine. Theor Appl Genet 77:212-216

Pohlheim F (1986) Hybrid variegation in crosses between Pelargonium zonale (L.) l'Herit. Ex Ait. and Pelargonium inquinans (L.) l'Herit. Ex. Ait. Plant Breed 97:93-96

Small I, Suffolk R, Leaver CJ (1989) Evolution of plant mitochondrial genomes via substoichiometric intermediates. Cell 58:69-76

Stubbe W (1989) Oenothera: an ideal system for studying the interactions of genome and plastome. Plant Mol Biol Rep $7: 245-257$

Sutovsky P, Van Leyen K, McCauley T, Day BN, Sutovsky M (2004) Degradation of paternal mitochondria after fertilization: implications for heteroplasmy, assisted reproductive technologies and mtDNA inheritance. Reprod Biomed Online 8:24-33

Ujvari B, Dowton M, Madsen T (2007) Mitochondrial DNA recombination in a free-ranging Australian lizard. Biol Lett 3:189-192

Wallace DC (2007) Why do we still have a maternally inherited mitochondrial DNA? Insights from evolutionary medicine. Annu Rev Biochem 76:781-821

Zaegel V, Guermann B, Le Ret M, Andrés C, Meyer D, Erhardt M, Canaday J, Gualberto JM, Imbault P (2006) The plant-specific ssDNA binding protein OSB1 is involved in the stoichiometric transmission of mitochondrial DNA in Arabidopsis. Plant Cell 18:3548-3563

Zhang Q, Liu Y, Sodmergen (2003) Examination of the cytoplasmic DNA in male reproductive cells to determine the potential for cytoplasmic inheritance in 295 angiosperm species. Plant Cell Physiol 44:941-951 